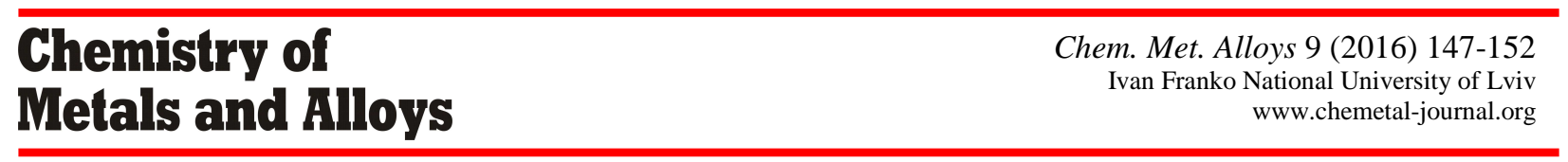

\title{
Crystal structure of $\mathrm{Cs}_{8}\left[\mathrm{~W}_{2}(\mathrm{CN})_{16}\right] \cdot 3 \mathrm{H}_{2} \mathrm{O}$
}

\author{
Dariya SEMENYSHYN ${ }^{1}$, Iryna TYPILO ${ }^{1}$, Marek DASZKIEWICZ $^{2}$, Lubomir GULAY $^{3}$ \\ ${ }^{1}$ Institute of Chemistry and Chemical Engineering, National University "Lvivska Polytechnika”, \\ Bandera St. 12, UA-79013 Lviv, Ukraine \\ 2 Institute of Low Temperature and Structure Research, Polish Academy of Sciences, \\ P.O. Box 1410, 50-950 Wroctaw, Poland \\ ${ }^{3}$ Department of Ecology and Protection of Environment, Eastern European National University, \\ Voli Ave. 13, 43009 Lutsk, Ukraine \\ * Corresponding author. Tel.: +380-676759235; e-mail: semenyshyn@polynet.lviv.ua
}

Received October 31, 2016; accepted December 28, 2016; available on-line August 14, 2017

The $\mathrm{Cs}_{8}\left[\mathrm{~W}_{2}(\mathrm{CN})_{16}\right] \cdot 3 \mathrm{H}_{2} \mathrm{O}$ compound crystallizes in the monoclinic system (space group $P 2_{1} / c$ with cell

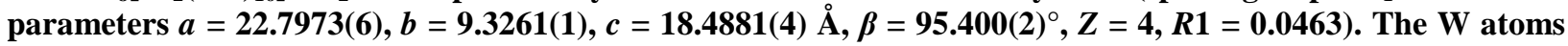
occupy two crystallographically independent sites and the coordination polyhedra of the tungsten atoms are distorted trigonal prisms $\left[\mathrm{W}(1)(\mathrm{CN})_{8}\right]$ and $\left[\mathrm{W}(2)(\mathrm{CN})_{8}\right]$ with two additional atoms. The Cs atoms occupy eight sites and exhibit various coordination polyhedra: distorted tetragonal antiprisms, distorted pentagonal bipyramids, trigonal prisms with one addition atom, trigonal prisms with two additional atoms, and a 9-vertex polyhedron of irregular shape.

\section{Cesium octacyanotungstate(IV) / Crystal structure / X-ray single crystal diffraction}

\section{Introduction}

In recent years there has been strong interest in the study of octacyanide complexes of $s-d$ elements due to their interesting physical properties. They may indeed have good sorption, magnetic, optical and other properties.

The earliest reported cyanide tungsten $(\mathrm{IV}, \mathrm{V})$ complexes were $\mathrm{K}_{3}\left[\mathrm{~W}(\mathrm{CN})_{8}\right] \quad[1,2] \quad$ and $\mathrm{K}_{4}\left[\mathrm{~W}(\mathrm{CN})_{8}\right] \cdot 2 \mathrm{H}_{2} \mathrm{O}[1,3]$. Small soluble salts $\mathrm{Ag}_{4}[R]$, $\mathrm{Mn}_{2}[R], \quad \mathrm{Tl}_{4}[R], \quad \mathrm{Cd}_{2}[R] \cdot \mathrm{H}_{2} \mathrm{O}, \quad \mathrm{Zn}_{2}[R] \cdot 4 \mathrm{H}_{2} \mathrm{O}$, where $R=\left[\mathrm{W}(\mathrm{CN})_{8}\right]^{4-}[4,5]$ were selectively obtained using reaction deposition. Readily soluble salts such as: $\mathrm{Na}_{4}[R] \cdot \mathrm{H}_{2} \mathrm{O}, \mathrm{Rb}_{4}[R] \cdot 3 \mathrm{H}_{2} \mathrm{O}, \mathrm{Sr}_{2}[R] \cdot \mathrm{H}_{2} \mathrm{O}, \mathrm{Cd}_{2}[R] \cdot 8 \mathrm{H}_{2} \mathrm{O}$, $\mathrm{Mg}_{2}[R] \cdot 6 \mathrm{H}_{2} \mathrm{O}, \mathrm{Rb}_{4}[R] \cdot \mathrm{H}_{2} \mathrm{O}$, and $\mathrm{Li}_{4}[R] \cdot \mathrm{H}_{2} \mathrm{O}[4,5]$ were obtained by exchange reaction of $\mathrm{Ag}_{4}\left[\mathrm{~W}(\mathrm{CN})_{8}\right]$ and metal chlorides. The complex acids $\mathrm{H}_{4}\left[\mathrm{~W}(\mathrm{CN})_{8}\right] \cdot \mathrm{H}_{2} \mathrm{O}$ $[1,5], \quad \mathrm{H}_{4}\left[\mathrm{~W}(\mathrm{CN})_{8}\right] \cdot 2 \mathrm{H}_{2} \mathrm{O}, \quad \mathrm{H}_{3}\left[\mathrm{~W}(\mathrm{CN})_{8}\right] \cdot \mathrm{H}_{2} \mathrm{O} \quad[6]$, $\mathrm{H}_{4}\left[\mathrm{~W}(\mathrm{CN})_{8}\right] \cdot 6 \mathrm{H}_{2} \mathrm{O}[6,7]$ should also be mentioned. The complexes $\mathrm{Cs}_{3}\left[\mathrm{~W}(\mathrm{CN})_{8}\right] \cdot 2 \mathrm{H}_{2} \mathrm{O}$ [8], $\mathrm{K}_{3}\left[\mathrm{~W}(\mathrm{CN})_{8}\right] \cdot \mathrm{H}_{2} \mathrm{O}, \quad \mathrm{Na}_{3}\left[\mathrm{~W}(\mathrm{CN})_{8}\right] \cdot 4 \mathrm{H}_{2} \mathrm{O}$, $\left[n-\mathrm{Bu}_{4} \mathrm{~N}\right]_{3}\left[\mathrm{~W}(\mathrm{CN})_{8}\right] \quad[9]$ and $\mathrm{K}_{4}\left[M(\mathrm{CN})_{8}\right]$, $\mathrm{K}_{4}\left[M(\mathrm{CN})_{6}\right], \mathrm{K}_{3}\left[M(\mathrm{CN})_{6}\right], \mathrm{K}_{3}\left[M(\mathrm{CN})_{8}\right],(M=\mathrm{Mo}, \mathrm{W})$, $\mathrm{K}_{2}\left[\mathrm{~W}(\mathrm{CN})_{5} \mathrm{H}_{2} \mathrm{O}\right]$ [10] have also been investigated.

One of the first crystal structures to be investigated was that of $\mathrm{K}_{4}\left[\mathrm{~W}(\mathrm{CN})_{8}\right] \cdot 2 \mathrm{H}_{2} \mathrm{O} \quad[11]$, which is isomorphic with $\mathrm{K}_{4}\left[\mathrm{Mo}(\mathrm{CN})_{8}\right] \cdot 2 \mathrm{H}_{2} \mathrm{O} \quad$ [12]. The coordination polyhedron $\left[\mathrm{W}(\mathrm{CN})_{8}\right]^{4-}$ in this compound has the shape of a dodecahedron. Antiprismatic tetragonal configuration (symmetry $D_{4 d}$ ) of the $\left[\mathrm{W}(\mathrm{CN})_{8}\right]^{4-}$ ion was established by X-ray diffraction for $\mathrm{H}_{4}\left[\mathrm{~W}(\mathrm{CN})_{8}\right] \cdot 6 \mathrm{H}_{2} \mathrm{O} \quad[7,13]$. In the compounds $\mathrm{H}_{4}\left[\mathrm{~W}(\mathrm{CN})_{8}\right] \cdot \mathrm{H}_{2} \mathrm{O}, \quad \mathrm{H}_{4}\left[\mathrm{~W}(\mathrm{CN})_{8}\right] \cdot 4 \mathrm{HCl} \cdot 12 \mathrm{H}_{2} \mathrm{O} \quad$ [14], $\mathrm{Kat}_{m}\left[\mathrm{~W}(\mathrm{CN})_{8}\right] \cdot n \mathrm{H}_{2} \mathrm{O}$, where Kat $=\mathrm{H}^{+}, \mathrm{Na}^{+}, \mathrm{Ca}^{2+}[4,5]$, and $\mathrm{Na}_{3}\left[\mathrm{~W}(\mathrm{CN})_{8}\right] \cdot 4 \mathrm{H}_{2} \mathrm{O}[4,5]$, the complex anions have antiprismatic configuration. Saramaha and Dovgej [15] described the synthesis and crystal structure of the compound $\mathrm{Na}_{3} \mathrm{H}_{3} \mathrm{O}\left[\mathrm{W}(\mathrm{CN})_{8}\right] \cdot 2 \mathrm{H}_{2} \mathrm{O}$, in which the anion $\left[\mathrm{W}(\mathrm{CN})_{8}\right]^{4-}$ has dodecahedral shape. The crystal structure of the complex $\mathrm{Rb}_{4}\left[\mathrm{~W}(\mathrm{CN})_{8}\right] \cdot 2 \mathrm{H}_{2} \mathrm{O} \quad[16]$ is isostructural with $\mathrm{K}_{4}\left[\mathrm{~W}(\mathrm{CN})_{8}\right] \cdot 2 \mathrm{H}_{2} \mathrm{O}$.

It appears that the crystal structures of octacyanotungstate(IV) complexes of alkali metal cations have been determined only for a few compounds. With the aim to study the effect of the nature of the outer $s$-cation on the structures of octacyanotungstates(IV) of alkali metals, we synthesized and investigated the crystal structure of a new compound, the cesium octacyanotungstate(IV) sesquihydrate $\mathrm{Cs}_{8}\left[\mathrm{~W}_{2}(\mathrm{CN})_{16}\right] \cdot 3 \mathrm{H}_{2} \mathrm{O}$.

\section{Experimental}

Synthesis

Octacyanotungstate(IV) acid required for the synthesis of the complex was obtained by passing a solution of 
$\mathrm{K}_{4}\left[\mathrm{~W}(\mathrm{CN})_{8}\right] \cdot 2 \mathrm{H}_{2} \mathrm{O}$ through a cation exchanger $\mathrm{KU}-2$ in $\mathrm{H}^{+}$-form. A $\mathrm{Cs}_{8}\left[\mathrm{~W}_{2}(\mathrm{CN})_{16}\right] \cdot 3 \mathrm{H}_{2} \mathrm{O}$ powder sample was prepared by mixing aqueous solutions of $\mathrm{H}_{4}\left[\mathrm{~W}(\mathrm{CN})_{8}\right]$ and cesium carbonate. The resulting solution was submitted to slow crystallization at room temperature in a dark place. A few weeks later crystals suitable for X-ray diffraction studies had formed. The yield of isolated product was $65 \%$. The composition of the single crystal used for the structure determination was confirmed by EDX analysis (EDAX PV9800 microanalyzer).

\section{X-ray diffraction}

X-ray diffraction data were collected on a KUMA Diffraction KM-4 four-circle diffractometer equipped with a CCD camera, using graphite-monochromatized Mo $K \alpha$ radiation $(\lambda=0.71073 \AA)$. The raw data were treated with the CrysAlis Data Reduction program [17], taking into account an absorption correction. The intensities of the reflections were corrected for Lorentz and polarization factors. The crystal structure was solved by the Patterson method and refined by the full-matrix least-squares method using SHELXL-97 [18].

\section{Results and discussion}

Details of the structure investigation of $\mathrm{Cs}_{8}\left[\mathrm{~W}_{2}(\mathrm{CN})_{16}\right] \cdot 3 \mathrm{H}_{2} \mathrm{O}$ are given in Table 1 , whereas the atomic coordinates and equivalent (isotropic) displacement parameters are listed in Table 2. The displacement parameters of the $\mathrm{C}$ and $\mathrm{N}$ atoms were refined in isotropic approximation. Selected bond lengths and angles are listed in Table 3.

The content of one unit cell of $\mathrm{Cs}_{8}\left[\mathrm{~W}_{2}(\mathrm{CN})_{16}\right] \cdot 3 \mathrm{H}_{2} \mathrm{O}$ and the coordination polyhedra of the $\mathrm{W}$ atoms are shown in Fig. 1. The structure of $\mathrm{Cs}_{8}\left[\mathrm{~W}_{2}(\mathrm{CN})_{16}\right] \cdot 3 \mathrm{H}_{2} \mathrm{O}$ consists of individual $\left[\mathrm{W}(\mathrm{CN})_{8}\right]^{4-}$ ions, which are located between the cesium cations and water molecules. The tungsten atoms in the structure occupy two distinct sites. Each tungsten atom is surrounded by eight cyano groups in the form of a trigonal prism with two additional atoms (Fig. 1). The shortest W1-C and W2-C distances are in the ranges 2.14(2)-2.171(17) and 2.112(17)2.174(16) $\AA$, respectively. The bond lengths of $\mathrm{C} \equiv \mathrm{N}$ at the $\mathrm{W} 1$ and $\mathrm{W} 2$ atoms have values within 1.140(19)$1.178(18)$ and 1.12(3)-1.177(18) $\AA$, respectively. The $\mathrm{W}-\mathrm{CN}$ angles vary from $172.9(19)$ to $178.4(18)^{\circ}$ for $\mathrm{W} 1$ and from 175.1(19) to $179.1(19)^{\circ}$ for $\mathrm{W} 2$.

Table 1 Experimental details of the structure refinement for $\mathrm{Cs}_{8}\left[\mathrm{~W}_{2}(\mathrm{CN})_{16}\right] \cdot 3 \mathrm{H}_{2} \mathrm{O}$.

\begin{tabular}{|c|c|}
\hline \multicolumn{2}{|c|}{ Parameters and their values } \\
\hline Crystal color & yellow \\
\hline Empirical formula & $\mathrm{C}_{16} \mathrm{H}_{6} \mathrm{~N}_{16} \mathrm{O}_{3} \mathrm{Cs}_{8} \mathrm{~W}_{2}$ \\
\hline$M_{\mathrm{r}}$ & 1901.35 \\
\hline System & monoclinic \\
\hline Space group & $P 2_{1} / c$ \\
\hline Cell parameters $(\AA)$ & $\begin{array}{l}a=22.7973(6) \\
b=9.32614(18) \\
c=18.4881(4) \\
\beta=95.400(2)^{\circ}\end{array}$ \\
\hline$V\left(\AA^{3}\right)$ & $3913.34(16)$ \\
\hline Formula units per cell, $Z$ & 4 \\
\hline Density, $D_{\mathrm{x}}\left(\mathrm{g} \mathrm{cm}^{-3}\right)$ & 3.227 \\
\hline$\mu\left(\mathrm{mm}^{-1}\right)$ & 13.251 \\
\hline$F(000)$ & 3304 \\
\hline Radiation & Mo $K \alpha$ \\
\hline$\lambda(\AA)$ & 0.71073 \\
\hline Range $\theta\left(^{\circ}\right)$ & $2.97<\theta<26.02$ \\
\hline Index ranges & $-10 \leq h \leq 10,-11 \leq k \leq 11,-22 \leq l \leq 22$ \\
\hline Number of measured reflections & 24859 \\
\hline Number of independent reflections & 4119 \\
\hline Number of reflections with $I>2 \sigma(I)$ & 2918 \\
\hline$R_{\text {int }}$ & 0.0663 \\
\hline Number of refined parameters & 231 \\
\hline Goodness of fit on $F^{2}$ & 1.166 \\
\hline$R[I>2 \sigma(I)]$ & $R 1=0.0463, w R 2=0.0754$ \\
\hline$R$ (all data) & $R 1=0.0849, w R 2=0.0894$ \\
\hline$\Delta \rho_{\min } / \Delta \rho_{\max }\left(\mathrm{e} \AA^{-3}\right)$ & $-0.952 / 1.451$ \\
\hline
\end{tabular}


Table 2 Atomic coordinates and equivalent/isotropic displacement parameters for $\mathrm{Cs}_{8}\left[\mathrm{~W}_{2}(\mathrm{CN})_{16}\right] \cdot 3 \mathrm{H}_{2} \mathrm{O}$.

\begin{tabular}{|c|c|c|c|c|c|}
\hline Atom & $\begin{array}{l}\text { Wyckoff } \\
\text { position }\end{array}$ & $x$ & $y$ & $z$ & $U_{\text {eq }} / U_{\text {iso }}\left(\AA^{2}\right)$ \\
\hline W1 & $4 e$ & $0.14339(5)$ & $0.70792(7)$ & $0.60056(3)$ & $0.0261(4)$ \\
\hline W2 & $4 e$ & $0.38277(5)$ & $0.23409(7)$ & $0.34641(3)$ & $0.0248(4)$ \\
\hline Cs1 & $4 e$ & $0.48034(7)$ & $0.33079(11)$ & $0.17332(6)$ & $0.0360(6)$ \\
\hline Cs2 & $4 e$ & $0.24615(7)$ & $0.81959(12)$ & $0.43387(6)$ & $0.0431(6)$ \\
\hline Cs3 & $4 e$ & $0.34465(8)$ & $0.72890(12)$ & $0.24609(7)$ & $0.0488(6)$ \\
\hline Cs4 & $4 e$ & $0.41862(7)$ & $0.62898(13)$ & $0.53278(6)$ & $0.0460(6)$ \\
\hline Cs5 & $4 e$ & $0.18735(7)$ & $0.40027(12)$ & $0.26902(6)$ & $0.0490(6)$ \\
\hline Cs6 & $4 e$ & $0.27680(8)$ & $0.30686(12)$ & $0.56227(7)$ & $0.0549(6)$ \\
\hline Cs7 & $4 e$ & $0.06348(8)$ & $0.28734(14)$ & $0.04657(7)$ & $0.0606(7)$ \\
\hline Cs8 & $4 e$ & $0.08315(8)$ & $0.98404(14)$ & $0.29969(7)$ & $0.0680(7)$ \\
\hline $\mathrm{O} 1$ & $4 e$ & $0.0267(9)$ & $0.6817(18)$ & $0.3157(9)$ & $0.119(7)$ \\
\hline $\mathrm{O} 2$ & $4 e$ & $0.3417(8)$ & $-0.0314(15)$ & $0.5525(8)$ & $0.096(6)$ \\
\hline $\mathrm{O} 3$ & $4 e$ & $0.0909(10)$ & $0.290(2)$ & $0.3711(10)$ & $0.151(8)$ \\
\hline N1 & $4 e$ & $0.3940(8)$ & $-0.1039(15)$ & $0.4064(7)$ & $0.044(4)$ \\
\hline N2 & $4 e$ & $0.3904(8)$ & $0.0308(14)$ & $0.2003(7)$ & $0.042(4)$ \\
\hline N3 & $4 e$ & $0.4227(8)$ & $0.2653(15)$ & $0.5212(8)$ & $0.055(5)$ \\
\hline N4 & $4 e$ & $0.3021(8)$ & $0.4988(16)$ & $0.4046(7)$ & $0.050(5)$ \\
\hline N5 & $4 e$ & $0.3304(8)$ & $0.4071(14)$ & $0.1971(7)$ & $0.042(4)$ \\
\hline N6 & $4 e$ & $0.4572(8)$ & $0.5409(16)$ & $0.3523(7)$ & $0.053(5)$ \\
\hline N7 & $4 e$ & $0.1542(8)$ & $0.4972(15)$ & $0.4585(7)$ & $0.047(5)$ \\
\hline N8 & $4 e$ & $0.0746(8)$ & $0.8861(15)$ & $0.4623(7)$ & $0.048(5)$ \\
\hline N9 & $4 e$ & $0.2019(8)$ & $1.0270(16)$ & $0.5859(7)$ & $0.051(5)$ \\
\hline N10 & $4 e$ & $0.2463(10)$ & $0.1110(18)$ & $0.3462(8)$ & $0.066(6)$ \\
\hline N11 & $4 e$ & $0.0584(9)$ & $0.9342(18)$ & $0.6758(9)$ & $0.065(5)$ \\
\hline N12 & $4 e$ & $0.0145(11)$ & $0.553(2)$ & $0.5968(9)$ & $0.077(7)$ \\
\hline $\mathrm{N} 13$ & $4 e$ & $0.2017(8)$ & $0.7520(13)$ & $0.7711(7)$ & $0.036(4)$ \\
\hline N15 & $4 e$ & $0.1620(7)$ & $0.3758(14)$ & $0.6666(7)$ & $0.038(4)$ \\
\hline N14 & $4 e$ & $0.5238(10)$ & $0.1721(14)$ & $0.3391(7)$ & $0.034(5)$ \\
\hline N16 & $4 e$ & $0.2854(10)$ & $0.6508(14)$ & $0.5889(7)$ & $0.034(5)$ \\
\hline $\mathrm{C} 1$ & $4 e$ & $0.3907(9)$ & $0.0148(17)$ & $0.3861(8)$ & $0.032(5)$ \\
\hline $\mathrm{C} 2$ & $4 e$ & $0.3870(9)$ & $0.0993(16)$ & $0.2515(8)$ & $0.030(5)$ \\
\hline $\mathrm{C} 3$ & $4 e$ & $0.4061(10)$ & $0.2513(17)$ & $0.4594(9)$ & $0.040(5)$ \\
\hline $\mathrm{C} 4$ & $4 e$ & $0.3280(10)$ & $0.4022(18)$ & $0.3847(8)$ & $0.032(5)$ \\
\hline C5 & $4 e$ & $0.3484(9)$ & $0.3453(17)$ & $0.2501(8)$ & $0.033(5)$ \\
\hline C6 & $4 e$ & $0.4315(9)$ & $0.4345(17)$ & $0.3488(8)$ & $0.029(5)$ \\
\hline $\mathrm{C} 7$ & $4 e$ & $0.1482(10)$ & $0.5718(19)$ & $0.5061(9)$ & $0.046(6)$ \\
\hline $\mathrm{C} 8$ & $4 e$ & $0.0968(10)$ & $0.8172(17)$ & $0.5087(9)$ & $0.035(5)$ \\
\hline C9 & $4 e$ & $0.1853(9)$ & $0.9124(17)$ & $0.5921(8)$ & $0.031(5)$ \\
\hline C10 & $4 e$ & $0.2942(12)$ & $0.1491(19)$ & $0.3449(9)$ & $0.039(6)$ \\
\hline $\mathrm{C} 11$ & $4 e$ & $0.0849(12)$ & $0.849(2)$ & $0.6496(10)$ & $0.061(7)$ \\
\hline C12 & $4 e$ & $0.0586(13)$ & $0.606(2)$ & $0.5970(10)$ & $0.051(6)$ \\
\hline C13 & $4 e$ & $0.1794(9)$ & $0.7377(16)$ & $0.7114(8)$ & $0.030(5)$ \\
\hline C14 & $4 e$ & $0.4735(15)$ & $0.1889(18)$ & $0.3418(8)$ & $0.035(6)$ \\
\hline $\mathrm{C} 15$ & $4 e$ & $0.1554(10)$ & $0.4930(18)$ & $0.6446(8)$ & $0.036(5)$ \\
\hline C16 & $4 e$ & $0.2364(14)$ & $0.6684(16)$ & $0.5947(8)$ & $0.026(5)$ \\
\hline
\end{tabular}

The cesium atoms occupy eight crystallographic positions and have different coordination polyhedra: $\mathrm{Cs}(1) \mathrm{N}_{7}$ - a pentagonal bipyramid, $\mathrm{Cs}(2) \mathrm{N}_{7} \mathrm{O}-\mathrm{a}$ deformed tetragonal antiprism, $\mathrm{Cs}(3) \mathrm{N}_{7}$ - a slightly deformed trigonal prism with one additional atom, $\mathrm{Cs}(4) \mathrm{N}_{8} \mathrm{O}-\mathrm{a} 9$-vertex polyhedron of undefined shape, $\mathrm{Cs}(5) \mathrm{N}_{7} \mathrm{O}-$ a slightly deformed trigonal prism with two additional atoms, $\mathrm{Cs}(6) \mathrm{N}_{7} \mathrm{O}-$ a trigonal prism with two additional atoms, $\operatorname{Cs}(7) \mathrm{N}_{6} \mathrm{O}_{2}-$ a deformed trigonal prism with two additional atoms, $\mathrm{Cs}(8) \mathrm{N}_{4} \mathrm{O}_{3}-\mathrm{a}$ deformed trigonal prism with one additional atom. The coordination polyhedra of the cesium atoms in the structure of $\mathrm{Cs}_{8}\left[\mathrm{~W}_{2}(\mathrm{CN})_{16}\right] \cdot 3 \mathrm{H}_{2} \mathrm{O}$ are shown in Fig. 2. 
Table 3 Selected bond lengths and angles for $\mathrm{Cs}_{8}\left[\mathrm{~W}_{2}(\mathrm{CN})_{16}\right] \cdot 3 \mathrm{H}_{2} \mathrm{O}$.

\begin{tabular}{l|l|l|l|l|l}
\hline \multicolumn{1}{c|}{ Atoms } & \multicolumn{1}{c|}{$\delta(\AA)$} & \multicolumn{1}{c|}{ Atoms } & \multicolumn{1}{c}{$\delta(\AA)$} & \multicolumn{1}{c}{ Atoms } & \multicolumn{1}{c}{$\omega\left(^{\circ}\right)$} \\
\hline W1-C11 & $2.14(2)$ & C1-N1 & $1.169(18)$ & W1-C7N7 & $176.0(2)$ \\
W1-C9 & $2.145(18)$ & C2-N2 & $1.151(17)$ & W1-C8N8 & $174.0(16)$ \\
W1-C12 & $2.15(3)$ & C3-N3 & $1.177(19$ & W1-C9N9 & $172.9(19)$ \\
W1-C13 & $2.153(16)$ & C4-N4 & $1.16(2)$ & W1-C11N11 & $173.0(2)$ \\
W1-C16 & $2.16(3)$ & C5-N5 & $1.178(18)$ & W1-C12N12 & $178.4(18)$ \\
W1-C8 & $2.170(17)$ & C6-N6 & $1.151(19)$ & W1-C13N13 & $176.9(18)$ \\
W1-C7 & $2.170(18)$ & C7-N7 & $1.140(19)$ & W1-C15N15 & $178.2(14)$ \\
W1-C15 & $2.171(17)$ & C8-N8 & $1.152(19)$ & W1-C16N16 & $177.1(14)$ \\
W2-C3 & $2.112(17)$ & C9-N9 & $1.144(19)$ & W2-C1N1 & $178.6(18)$ \\
W2-C14 & $2.12(3)$ & C10-N10 & $1.13(2)$ & W2-C2N2 & $177.9(17)$ \\
W2-C5 & $2.144(16)$ & C11-N11 & $1.142(18)$ & W2-C3N3 & $175.3(19)$ \\
W2-C4 & $2.164(19)$ & C12-N12 & $1.12(3)$ & W2-C4N4 & $175.1(19)$ \\
W2-C10 & $2.17(3)$ & C13-N13 & $1.177(18)$ & W2-C5N5 & $179.1(14)$ \\
W2-C2 & $2.168(15)$ & C14-N14 & $1.16(3)$ & W2-C6N6 & $177.9(15)$ \\
W2-C6 & $2.173(18)$ & C15-N15 & $1.171(17)$ & W2-C10N10 & $176.0(18)$ \\
W2-C1 & $2.174(16)$ & C16-N16 & $1.14(3)$ & W2-C14N14 & $176.3(16)$ \\
\hline
\end{tabular}
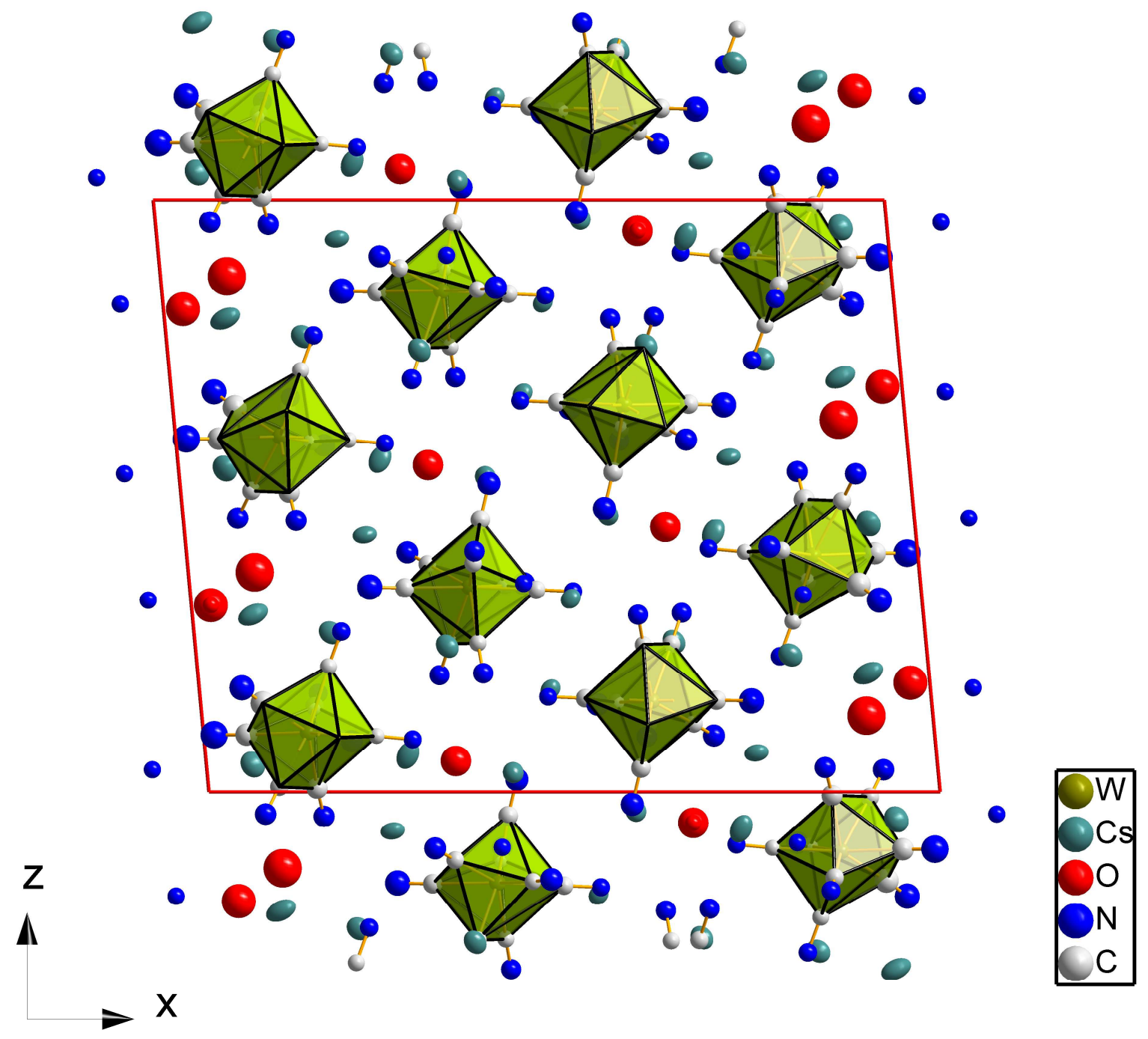

Fig. 1 Unit cell of $\mathrm{Cs}_{8}\left[\mathrm{~W}_{2}(\mathrm{CN})_{16}\right] \cdot 3 \mathrm{H}_{2} \mathrm{O}$ and coordination polyhedra of the $\mathrm{W}$ atoms. 


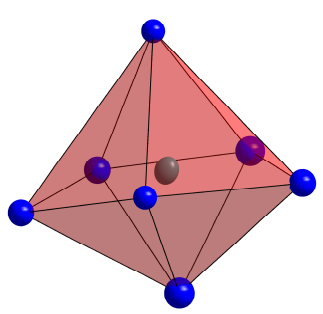

$$
\operatorname{Cs}(1) \mathrm{N}_{7}
$$

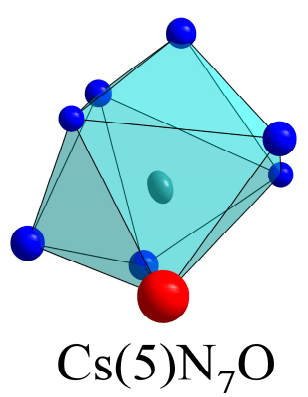

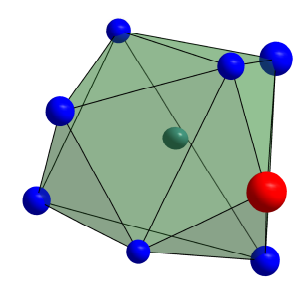

$\mathrm{Cs}(2) \mathrm{N}_{7} \mathrm{O}$

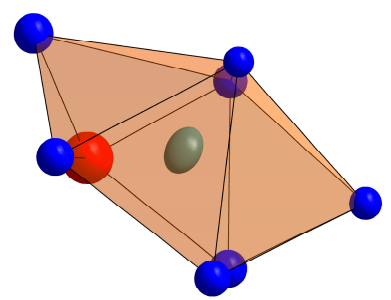

$\mathrm{Cs}(6) \mathrm{N}_{7} \mathrm{O}$

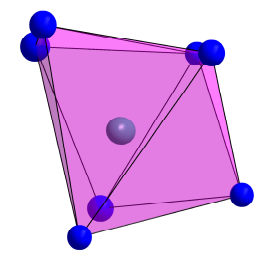

$\operatorname{Cs}(3) \mathrm{N}_{7}$

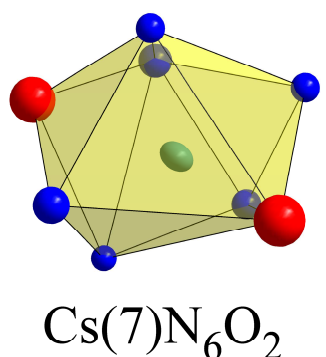

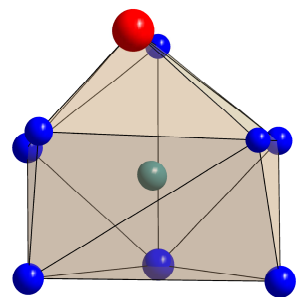

$\mathrm{Cs}(4) \mathrm{N}_{8} \mathrm{O}$

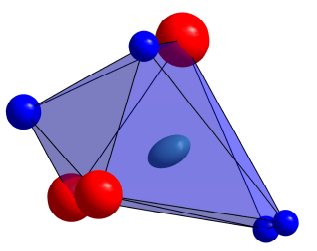

$\mathrm{Cs}(8) \mathrm{N}_{4} \mathrm{O}_{3}$

Fig. 2 Coordination polyhedra of the cesium atoms in $\mathrm{Cs}_{8}\left[\mathrm{~W}_{2}(\mathrm{CN})_{16}\right] \cdot 3 \mathrm{H}_{2} \mathrm{O}$.

\section{Conclusions}

The crystal structure of the $\mathrm{Cs}_{8}\left[\mathrm{~W}_{2}(\mathrm{CN})_{16}\right] \cdot 3 \mathrm{H}_{2} \mathrm{O}$ $\left(\mathrm{Cs}_{4}\left[\mathrm{~W}(\mathrm{CN})_{8}\right] \cdot 1.5 \mathrm{H}_{2} \mathrm{O}\right)$ complex differs significantly from the structures of the complexes $\mathrm{K}_{4}\left[\mathrm{~W}(\mathrm{CN})_{8}\right] \cdot 2 \mathrm{H}_{2} \mathrm{O}[11], \mathrm{Rb}_{4}\left[\mathrm{~W}(\mathrm{CN})_{8}\right] \cdot 2 \mathrm{H}_{2} \mathrm{O}[16]$, and $\mathrm{K}_{4}\left[\mathrm{Mo}(\mathrm{CN})_{8}\right] \cdot 2 \mathrm{H}_{2} \mathrm{O}[12,19]$, which are isomorphous, and from the molybdenum complexes $\left(\mathrm{NH}_{4}\right)_{4}\left[\mathrm{Mo}(\mathrm{CN})_{8}\right] \cdot 0.5 \mathrm{H}_{2} \mathrm{O}$ and $\mathrm{Rb}_{4}\left[\mathrm{Mo}(\mathrm{CN})_{8}\right] \cdot 3 \mathrm{H}_{2} \mathrm{O}$ [20], which have different crystal structures. The size of the cesium cation $\left(r\left(\mathrm{Cs}^{+}\right)=1.65 \AA\right)$ differs significantly the sizes of the potassium, ammonium and rubidium cations $\left(r\left(\mathrm{~K}^{+}\right)=1.33, r\left(\mathrm{NH}_{4}{ }^{+}\right)=1.43\right.$, $\left.r\left(\mathrm{Rb}^{+}\right)=1.49 \AA\right)$. Therefore the tungsten compounds with cesium are not isostructural.

Besides, changing the number of water molecules in the complexes of molybdenum with ammonium $\left(\mathrm{NH}_{4}\right)_{4}\left[\mathrm{Mo}(\mathrm{CN})_{8}\right] \cdot 0.5 \mathrm{H}_{2} \mathrm{O}$ and rubidium $\mathrm{Rb}_{4}\left[\mathrm{Mo}(\mathrm{CN})_{8}\right] \cdot 3 \mathrm{H}_{2} \mathrm{O}$ leads to significant differences in the structures, which belong to different space groups. The molybdenum atoms in the $\left(\mathrm{NH}_{4}\right)_{4}\left[\mathrm{Mo}(\mathrm{CN})_{8}\right] \cdot 0.5 \mathrm{H}_{2} \mathrm{O}$ compound occupy two distinct positions and have different coordination polyhedra: $\quad\left[\mathrm{Mo} 1(\mathrm{CN})_{8}\right]^{4-}$ dodecahedra and $\left[\mathrm{Mo} 2(\mathrm{CN})_{8}\right]^{4-}$ tetragonal antiprisms. The coordination polyhedra of the molybdenum atoms in the structure of the $\mathrm{Rb}_{4}\left[\mathrm{Mo}(\mathrm{CN})_{8}\right] \cdot 3 \mathrm{H}_{2} \mathrm{O}$ compound are exclusively dodecahedra. Already in 1985 [20] the authors emphasized the influence of the number of molecules of crystallization water on the crystal structures of alkaline metal octacyanotungstates(IV). The
$\mathrm{Rb}_{4}\left[\mathrm{~W}(\mathrm{CN})_{8}\right] \cdot 2 \mathrm{H}_{2} \mathrm{O} \quad[16]$ and $\mathrm{Rb}_{4}\left[\mathrm{Mo}(\mathrm{CN})_{8}\right] \cdot 3 \mathrm{H}_{2} \mathrm{O}$ [20] complexes with different structures also contain different numbers of water molecules.

\section{References}

[1] A.R. Rosenheim, E.A. Dehn, Ber. Dtsch. Chem. Ges. 47 (1914) 397-399.

[2] O.L. Olsson, Ber. Dtsch. Chem. Ges. 47 (1914) 417-420.

[3] A.R. Rosenheim, Ber. Dtsch. Chem. Ges. 48 (1915) 1170-1174.

[4] A.M. Golub, X. Keler, V.V. Skopenko, Chemistry of Pseudohalogenides. Kyiv, Vyshcha shkola, 1981, 360 p. (in Russian)

[5] H.E. Williams, Cyanogen Compounds: Their Chemistry, Detection and Estimation, Second edition, 1948, $432 \mathrm{p}$.

[6] A. Samotus, B. Kosowicz-Czajkowska, Rocz. Chem. 45 (1971) 1623-1626.

[7] H. Mohan, J. Inorg. Nucl. Chem. 38(7) (1976) 1303-1305.

[8] L.D.C. Bok, J.G. Leipoldt, S.S. Basson, Z. Anorg. Allg. Chem. 415(1) (1975) 81-83.

[9] P.M. Kiernon, W.P. Griffith, J. Chem. Soc., Dalton Trans. 11(23) (1975) 2489-2494.

[10] Y.R. Fowler, Y. Kleinberg, Inorg. Chem. 9(5) (1970) 1005-1009.

[11] H. Baadsgaard, W. Treadwell, Helv. Chim. Acta 38 (1955) 1669-1673. 
[12] J.L. Hoard, H.H. Nordsieck, J. Am. Chem. Soc. 61(10) (1939) 2853-2857.

[13] S.S. Basson, L.D.C. Bok, J.G. Leipold, Acta Crystallogr. 26(9) (1970) 1209-1216.

[14] L.D.C. Bok, J.G. Leipoldt, S.S. Basson, Z. Anorg. Allg. Chem. 392 (1972) 303-304.

[15] I.V. Saramaha, V.V. Dovgej, Ukr. Khim. Zh. 64(12) (1998) 87-92.

[16] I.V. Typilo, R.E. Gladyshevskii, D.I. Semenyshyn, Ukr. Khim. Zh. 76(10) (2010) 77-80.
[17] Oxford Diffraction, CrysAlis CCD and CrysAlis $R E D$, version 1.171.30.3, Oxford Diffraction Ltd, Abingdon, Oxfordshire, UK, 2006.

[18] G.M. Sheldrick, SHELXS-97, Universität Göttingen, Germany, 1999.

[19] I. Typilo, O. Sereda, H. Stoeckli-Evans, R. Gladyshevskii, D. Semenyshyn, Chem. Met. Alloys 3 (2010) 49-52.

[20] D.I. Semenyshyn, T. Glovjak, M.H. Mys'kiv, Koord. Khim. 11(1) (1985) 122-128. 